\title{
Industrial Development Conflicts in Modern Developmental State: Taiwan taken as an Example
}

\author{
An-Ting Cheng* \\ Department of Urban Development, University of Taipei, Taiwan
}

Submission: February 13, 2019; Published: March 15, 2019

*Corresponding author: An-Ting Cheng, Department of Urban Development, University of Taipei, Taiwan

\begin{abstract}
In this article, a brief introduction of the industrial development in Taiwan will be elaborated first. Then it will discuss the conflicts between industrial development and urbanization through the case of Kaohsiung City. The transformation of modern developmental state makes central government less power to dominate industry. Thus, the new development mode and relationships among society, local and central government should to be rebuilt in the future.
\end{abstract}

Keywords: Industrial land; Spatial Planning; Developmental State; Transformation

\section{The Historical Context of Economic Development}

The rapid growth of Taiwan's economy was contributed to manufacturing and a specific economic development model, developmental state strategy, in the later 20th century. As a developmental state, the government has high state autonomy; its decision-making organizations are composed by professional technocrats; the policy decision put a priority on economic development to facilitate rapid industrialization with positive interventions. In addition, government will subsidize strategic industries and provide the preferential loans for enterprises to promote the development of the emerging industries [1]. Shi-jie [2] also generalized three main features of developmental state. First, government highly intervenes markets and establishes the dedicated agencies (such as Ministry of International Trade and Industry in Japan, National Development Council in Taiwan, Economic Development Board in Singapore, etc.) to formulate developing strategies to lead the economic development [3]. Second, government adopts flexible industrial policies to support the strategic industries with various subsidies and safeguards. Third, government implements land reform with clear social policies, maintains social and economic equality to prevent serious political conflicts. The features mentioned above could be found in Taiwan's government as well, it was centralized and dominated industrial development to accumulate great wealth for Taiwan in a short time. In 1949, the Republic of China government withdrew to Taiwan, first invested in light industry to supply domestic demand market, and then turned to export after 1960. Since 1972, the gross production of heavy industry was finally equal to light industry; Taiwan transformed into an industrialized society afterward Shu-Yuan [4]. However, under the impacts of international political situation and economic environment in the early 1970s, Taiwan's government implemented "Ten Major Construction Projects" to strengthen infrastructures in terms of transportation, heavy industry and energy development to improve economy.

The Conflicts Between Industry Development and Urbanization

Kaohsiung, the biggest city in southern Taiwan, its total area is about 295,185 hectares including industrial land 4,330 hectares, is the most important place to support "Ten Major Construction Projects" and developed shipbuilding, steelmaking and petrochemical industry about 40 years. Kaohsiung was planned to construct as a port and military city since Japanese ruled period, it is still an important city of heavy industry now. The heavy industry in Kaohsiung includes iron and steel, shipbuilding, petrochemical and reefing industry (Figure 1).

Taiwan developed more heavy industry since the 1970s, aimed to produced plastics, synthetic rubber, synthetic fibers and chemicals for downstream manufacturers to reduce the dependence on foreign import and enhance the competitiveness of export processed products. The case which is going to discuss below is the Kaohsiung Refinery Park s in Houjing, Kaohsiung. The refinery park was located in urban area and surrounded with residential districts. Its refined naphtha since the early 1970 s because of national industrial policy. While with the democracy and environmental awareness grew in Taiwan's society, government's new refinery construction plan in 1987 was not as easy to carry out as before. Houjing residents expressed their 


\section{Civil Engineering Research Journal}

strong opposition to more heavy industry to protect their health and living quality. After negotiation, government and people reached an agreement to shut down the first and second refinery as soon as the new refinery's was finished. In addition, the new refinery has to move away after 25 years. The public awareness seems mature enough to affect national policies and implies the weakening government in the future.

In 2015, the last refinery in Kaohsiung Refinery Park was shut down, but the remaining 42 working storage tanks made Houjing people dissatisfy. The refinery in Houjing was not the last one in Kaohsiung, the conflicts between industrial development and urbanization will happen continuously. A downstream industrial park named Renda on the east side of Houjing, their local people's opposition became stronger after Houjing's achievement. People requested heavy industry move away before 2018 according to requirements in the 1998 urban plan. Heavy industry in Renda industrial park also encountered a challenge of transformation or relocation, the related discussions and administrative procedures are still in progress. Introspection from the perspective of spatial planning

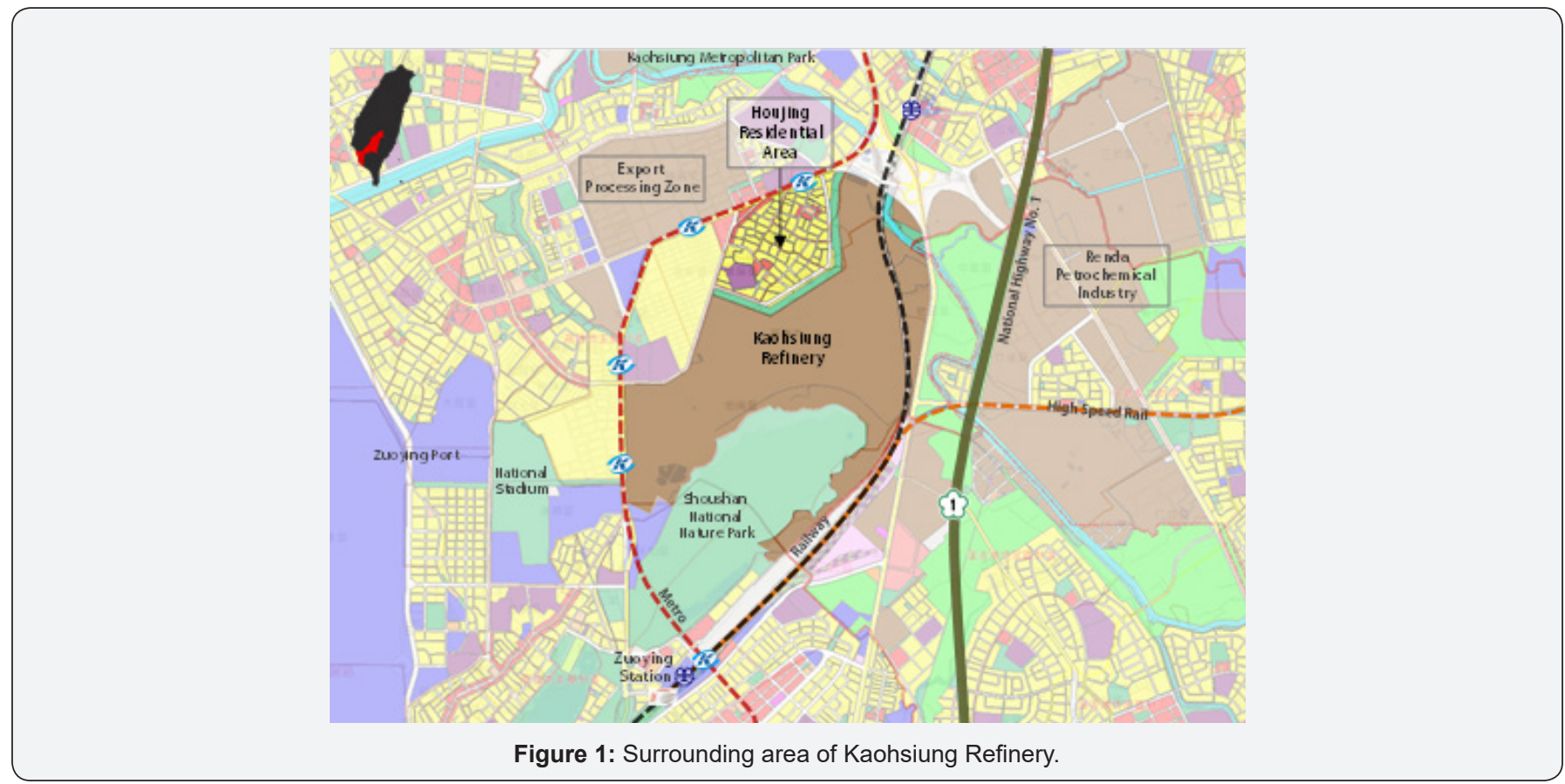

As urbanization, the suburb industrial land in the past now becomes down town area and threats living qualities to surrounding residents. While industry is an essential function to city's development and growth, the conflicts between urbanization and industrial development have to be mitigated, as well as the industrial land use control should be modified on the basis of contemporary society. In the past, centralized government made economic plans before spatial plans and made spatial plans operate in coordination with economic plans. However, Kaohsiung's experience reveals central government is hard to do the same thing and override spatial planning now.

This situation indicates the transformation of developmental state and reflects on its planning system. Numerous scholars believed that Taiwan's spatial planning system was transferred from earlier "blueprint planning" to "Neo-liberalism", but the state's functional role never disappeared [5-7]. With globalization, the modes of state's engagements become deeper into local connections over the world instead; which means Neo-liberalism intensifies the developmental state strategy [7].
Consequently, in Taiwan, government will keep playing a role in the future industrial development.

According to the white paper draft from the authority of economy in Taiwan, the expected cooperation will go to central government draw up the industrial policies and only focus on forward-looking industries. The constructions of industrial parks will shift to local government and enhance their authorization level to make industrial land more flexible and available to respond to markets in time. To the public, the authority of economy will elaborate industrial development policies through the white paper regularly and create more communications; see social and environmental departments as important as economic development. In addition, the National Spatial Plan will provide a platform allow all departments to negotiate their spatial development goals but not just fellow one department's domination. In this way, it might be a feasible mechanism to a transformed developmental state. It creates a new relationship by reducing appropriate power of central government and improving the decision level of local government to respond 


\section{Civil Engineering Research Journal}

markets in time, which becomes faster and changeable in modern society.

\section{Acknowledgment}

This work was supported by the Ministry of Science and Technology, Taiwan, R.O.C. [grant number MOST 104-2410-H214-017].

\section{References}

1. Tak-Wing N (2014) The Review and Reflection of Asian Experience: Restart of Developmental State Theory. In: Kam-Yee (Ed.), City University of Hong Kong, Hong Kong, China, p. 4-18.

2. Shi-jie W (2004) Post-authoritarian Period National Social Relations in Taiwan-State Capacity and Social Autonomy. National Chengchi University, Taipei, Taiwan.
3. National Development Council (2017) Urban and Regional Development Statistics (Report No. (106)022.0303).

4. Shu-Yuan K (2016) Taiwan Industrial History. Taipei, Taiwan.

5. Wang C (2012) Moving toward Neoliberalization? The Restructuring of the Developmental State and Spatial Planning in Taiwan. In: Park BG et al. (Eds.), East Asia: Neoliberalizing Spaces in Developmental States, Wiley-Blackwell, Oxford, US, pp. 167-195.

6. Yung-Jaan L, I-Chih, Juang L Han-Hwa J (2005) Global Shifts, Developmental State and the Town-Rural Planning Revisited in Taiwan-A Geographic Enquiry and Governance Crisis for the Adaptation of Urban Entrepreneurialism. Journal of Geographical Sciences 40: 69-97.

7. Chou, Tsu-Lung (2001) Cross-border Economy, Time-space Articulation and Restructuring Strategies of National Territory: A Comparison of Restructuring in Asian Fours. City and Plan 28(4): 461-494.

\section{Your next submission with Juniper Publishers will reach you the below assets}

- Quality Editorial service

- Swift Peer Review

- Reprints availability

- E-prints Service

- Manuscript Podcast for convenient understanding

- Global attainment for your research

- Manuscript accessibility in different formats

( Pdf, E-pub, Full Text, Audio)

- Unceasing customer service

Track the below URL for one-step submission https://juniperpublishers.com/online-submission.php 